\title{
The Spanish Parliament and legislative delegation $(1844-1849)^{1}$
}

\author{
EMILIA INESTA
}

\section{SUMMARY}

A study of executive power and the legislative elaboration process during the reign of Isabel II leads to an understanding of one of the government's distinctive features. During the rule of the Moderate Party (1844-1854), and despite the fact that according to the Constitution of 1845 the legislative initiative lay with the king and the parliament, the ministerial initiatives prevailed over parliamentary proposals by means of legislative delegation. The lack of constitutional regulation brought about the existence of several types of delegation. Contemporaries noted their excessive use arising from the fact that it was very easy to govern with this system and, above all, because they were granted to all governments without political distinction. A paradigmatic illustration of the use of delegation is the Spanish Penal Code of 1848. This was because of the scope of its contents (the code put an end to the Ancien Regime in Spain) and because it had a structure and a scientific orientation which were going to exert a recognised influence, not only on Spain's subsequent Spanish Penal Codes until reaching the one in force from 1995, but also in Latin America. The Penal Code was equally important, because it clearly shows how the chambers themselves were not only unable to limit the government's capacity to introduce law, but even enlarged it by conferring upon the latter extraordinary powers for its future reform, limited by the only condition that the government had to inform the chambers once the reforms had been completed. An analysis of parliamentary debates allows us to understand the position of the moderate and progressive parties towards this practice.

Emilia Iñesta, University of Alicante

${ }^{1}$ This study forms part of the Research Project DER2009-09193/JURI: Parlamentos y ciudades de la Corona de Aragón en la encrucijada de la crisis del Antiguo Régimen [Parliaments and cities of the crown of Aragon at the crossroads of the crisis of the Ancien Regime], funded by the Spanish Ministry of Science and Innovation. It is based on the documentation available in the archives of the Spanish Parliament, the interpretations of legislative delegation by contemporary jurists, in particular the abundant unpublished and handwritten documentation about the Penal Code of 1848, which can be found in the archive of the General Codification Commission of the Spanish Ministry of Justice and, finally, the most significant works of its commentators.

Parliaments, Estates \& Representation 30, April 2010. Published for the International Commission for the History of Representative \& Parliamentary Institutions by Routledge/Taylor \& Francis. (C) 2010 International Commission for the History of Representative and Parliamentary Institutions/Commission Internationale pour l'Histoire des Assemblées d' États. DOI: 10.1080/02606751003651207 
The expression 'Moderate Decade' is used in Spain to refer to the period between 1844 and 1854, during which the capacity to exercise government powers was in the hands of the moderate party. During this period, the main functions of the government rested on four basic pillars: law and order, security and protection of property, an overall policy of centralisation and standardisation, and, finally, the use of doctrinarism as the ideological foundation for this new stage. ${ }^{2}$

The new moderate political system took its final shape in the Constitution of 1845, which served the economic and political interests of property owners as well as those of an enlightened minority that would rule the country. ${ }^{3}$ Compared with that of 1837 , in force until then, the 1845 Constitution ${ }^{4}$ represented a step forward in a purely monarchical sense and a step backward in a purely constitutional sense. The constitutional statement of the principle of double representation or shared sovereignty, king-parliament, allowed the moderates to shape a new political regime within the representative system, based on the crown's control over political action through its ministers. ${ }^{5}$

However, a number of political practices became consolidated in Spain during the reign of Isabel II, and more precisely during the period known as the Moderate Decade, both being particularly revealing of the real structure of the nineteenthcentury Spanish state. Among them, the executive power's legislative intervention to the detriment of the parliament stood out.

Thus, with respect to the elaboration of laws, the silence of the 1845 Moderate Constitution and parliamentary practice favoured the configuration of the legislative initiative as an essential attribute of the government on the one hand, and the possibility for the executive power to ask the Parliament to delegate legislative powers or authorisations in its favour, on the other.

One can find a paradigmatic example of the way in which legislative delegation was used by the moderate governments in the Spanish Penal Code of 1848, not only for the scope of its contents, but also because it clearly demonstrates how the chambers themselves widened the government's legislative initiative.

\footnotetext{
${ }^{2}$ See L. López Puerta, Moderados y progresistas, (1833-1868) (Madrid, 1971). J. L. Comellas, Los Moderados en el poder (1844-1854) (Madrid, 1979), F. Canovas Sánchez, El Partido Moderado (Madrid, 1982), E. Terron, Sociedad e ideología en los orígenes de la España contemporánea (Barcelona, 1969), p. 157, L. Diez del Corral, El Liberalismo doctrinario (Madrid, 1945), A. Garrorena Morales, El Ateneo de Madrid y la teoría de la Monarquía liberal (1836 -1847) (Madrid, 1974), p. 520.

${ }^{3}$ J. L. Aranguren, Moral y sociedad. La moral social española en el siglo XIX (Madrid, 1974), pp. 63, 96-7.

${ }^{4}$ See from a general point of view J. Valera, Historia General de España de Modesto Lafuente (Barcelona, 1890), vol. 23, p. 1, M. A. Tomás Font de Mora, 'La preparación de la Constitución de 1845', Revista de Estudios Políticos 73, (1991), pp. 229-41, M. A. Medina Muñoz, 'La reforma constitucional de 1845', Revista de Estudios Políticos 203, (1975), pp. 75-105, F. Canovas Sánchez, El moderantismo y la Constitución española de 1845 (Madrid, 1982). The constitutional texts are in D. Sevilla Andrés, Constituciones y otras Leyes y Proyectos políticos de España (Madrid, 1969) vol. I.

${ }^{5}$ L. Sanchez Agesta, Historia del constitucionalismo español, pp. 232-5, M. Artola, Partidos y programas políticos. 1808-1936 (Madrid, 1947), vol. I, pp. 119-27, 182. A. Garrorena Morales, El Ateneo de Madrid, pp. 607-71, J. I. Marcuello Benedicto, La practica parlamentaria en el Reinado de Isabel II (Madrid, 1986), p. 28, J. I. Marcuello Benedicto 'La práctica del poder moderador de la Corona en la época de Isabel II', Revista de Estudios Políticos 53 (1987), pp. 197-236, J. I. Marcuello Benedicto, 'La Corona y la desnaturalización del parlamentarismo isabelino', in I. Burdiel (ed.), La política en el reinado de Isabel II, Ayer 29, ( 1998), pp. 29-30.
} 


\section{THE RELATIONSHIP BETWEEN THE LEGISLATIVE AND EXECUTIVE POWERS DURING THE MODERATE DEGADE}

In the legislative context, the 1845 Constitution established that the crown and the parliament should draw up the laws jointly (Art. 12). The right to initiate legislation corresponded to the king and to each one of the co-legislating bodies (Art. 35), but it was also recognised that the crown had an absolute and unlimited capacity to veto the law agreements adopted by these bodies (Art. 36). The executive power equally lay with the crown (Art. 43), which was granted the prerogative to issue decrees, regulations and instructions for the enforcement of laws (Art. 45, 1) through the ministers appointed and dismissed by the king (Art. 45, 10).

Nevertheless, the exercise of the legislative initiative was in fact carried out by the government. In this sense, the crown ministers of the time carried out a governmental function which was understood to be politically essential, with one of the most important acts being the exercise of the legislative initiative through the proposal of bills. ${ }^{6}$ On the other hand, the parliamentary chambers assumed a secondary role, focusing on the debate and presentation of amendments and on their approval or rejection. To all of this must be added the frequency with which governments requested legislative delegations or authorisations in their favour, to which we must in turn add the nature of the areas covered by them. ${ }^{7}$

Consequently, the exercise of the legislative initiative and the utilisation of legislative delegation become two essential factors that enable us to have an accurate picture of the position undertaken by Isabel II's governments in the law elaboration process. ${ }^{8}$ This also illustrates how the behaviour of the actors in the moderate system undermined or reinforced its characteristics. ${ }^{9}$

During the Moderate Decade, the process of discussing and passing laws followed the legislative procedure fixed in the regulations of the co-legislating bodies. ${ }^{10}$ In accordance with the Senate Regulations of 10 March 1847 and the Congress Regulations of 4 May in the same year, the bills of law presented by the government had firstly to be submitted to its sections, which thus became familiar with the contents of the bill. Next, each section had to choose a member of its staff who was entrusted with the task of forming a special commission responsible

${ }^{6}$ L. Sánchez Agesta, 'Gobierno y responsabilidad', Revista de Estudios Politicos 113-4, (1960), p. 37.

${ }^{7}$ An absolute majority of ministerial bills over parliamentary proposals of law can be inferred from the analysis of the legislative periods comprised between 1845 and 1853. J.A. Enrile Aleix, El Senado en la Década Moderada (1845-1854) (Madrid, 1980), p. 269. Marcuello Benedicto, La práctica parlamentaria, pp. 83-8, 249. E. Iñesta, 'Legal powers of the Spanish Senate during the Moderate Decade (18441854)', in Separation of Powers and Parliamentarism the Past and the Present law, doctrine, practice. 56rd conference of the international commission for the History of Representative and Parliamentary Institutions (Warsov, 2007), pp. 534-553.

$130 \quad{ }^{8}$ Marcuello Benedicto, La práctica parlamentaria, pp. 83-5, 88.

9J. Pro Ruiz, 'La práctica política de los gobiernos antiparlamentarios del final de la Década moderada (1851-54)', Revista de las Cortes Generales 12, (1987), p. 8.

${ }^{10}$ Regulations of the Congreso de los Diputados [Lower Chamber of the Spanish Parliament] of 4 May 1847 in Reglamentos del Congreso de los Diputados y de las Cortes (Madrid, 1977). Regulations for the internal governance of the Senado [Upper Chamber of the Spanish Parliament] of 10 March 1847 in Reglamentos del Senado (1834-1993) (Madrid, 1993). J. I. Marcuello Benedicto, 'Los Reglamentos de las Cortes en la época de Isabel II’, Revista de las Cortes Generales 4, (1985), pp. 155-96. 
for the preparation of a report. In that way, it was not only possible to reflect in the commission the pre-existing criteria identified during the chamber plenary session, but also to make the debates and the final voting in the plenary session more flexible and better focused. However, this system had a drawback: it was detrimental to the minority opinion. The commission in charge of drawing up a report thus became an organ specialised in the matter dealt with in the bill of law. ${ }^{11}$

The presentation of the final version of the report was followed by its discussion and voting at the corresponding chamber in a public session. It must be highlighted that the debate did not focus on the bill or the proposal of law presented by the government, but on the report that the special commission had prepared. ${ }^{12}$ Once the commission had passed its judgment, the report went through three reading sessions: (a) a discussion of the report in its entirety, (b) a detailed discussion of the part containing the provisions, and (c) voting on the whole report for its definitive approval. The discussions could not be completed until three members of parliament who supported the report and another three who were against it had intervened. ${ }^{13}$ Members of the commission responsible for the preparation of the report as well as ministers could take part in the discussion without restrictions. ${ }^{14}$ In the specific case of codes, several general discussions about the different books or titles could take place. ${ }^{15}$ Finally, the passing of laws required an absolute plurality of votes, in the presence of half of the total number of chamber members plus one, and the royal assent. ${ }^{16}$

Legislative delegation was not explicitly regulated in the 1845 Constitution. Although it was granted by means of a legal agreement reached in the parliament, the constitutional silence actually made it possible to grant several types of legislative delegations according to the scope and limits of the transfers requested by the government and depending on the guarantees offered by the latter for the subsequent monitoring of those delegations by the parliament. The government could ask for a legislative delegation to publish a bill of law on its own initiative. In this type of delegation, the bill of law in question was presented before the parliament attached to the legislative authorisation bill, but it was not meant to be processed according to the regulations. It was actually brought to the chamber, so that the parliament assembly could authorise the government to publish it as a law - without the need for discussion in parliament. This way, the bill did not have to go through the three required readings in the public plenary sessions of each one of the chambers, and the discussion and the voting focused on the bill of law for legislative authorisation. In other cases, the parliament was only informed about the matter to be legislated or the request could be limited to a confidence vote. ${ }^{17}$

\footnotetext{
${ }^{11}$ J.L. Paniagua Soto, 'El sistema de Comisiones en el Parlamento Español', Revista de la Facultad de Derecho de la Universidad Complutense de Madrid 10, (1986), p. 114.

${ }^{12}$ Art. 88. Reglamentos del Congreso, 1847.

${ }^{13}$ Art. 110. Reglamentos del Congreso, 1847.

${ }^{14}$ Art. 132. Reglamentos del Congreso. Art. 77. Reglamentos del Senado.

${ }^{15}$ Art. 112. Reglamentos del Congreso.

${ }^{16}$ Arts. 37 and 44. Constitution of 1845.

${ }^{17}$ Marcuello Benedicto, La práctica parlamentaria, pp. 98-9. E. Virgala Foruria, La delegación legislativa en la Constitución y los decretos legislativos como normas con rango incondicionado de ley (Madrid, 1991), pp. 11-33.
} 
The sense and scope of legislative delegation was differently interpreted by 'moderates' and 'progressives'. The latter considered them unconstitutional on the basis of the legislative power shared by the parliament with the king and the principle of regulatory self-normativity, a guarantee of independence for the chambers, without the latter being able to renounce power in favour of the executive during the parliamentary processing. The moderate governments held a different stance, as they defended the constitutional nature of the delegations taking the absence of an express constitutional prohibition and the undervaluing of the binding strength of parliamentary regulations as a basis, as they considered that these regulations did not have the force of a law. However, in their view, legislative delegation necessarily had to be granted through a law approved by the parliament. This opinion, known at the time as 'parliamentary omnipotence' entailed a clear limitation of the representative system, since it not only meant that the chambers abdicated their legislative powers; it was also a way to silence the opposition minorities who found a guarantee in the detailed public discussion of the parts of the laws which contained the provisions. ${ }^{18}$

The significance and utility of ruling by means of legislative authorisation or delegation was already described by contemporaries. Juan Rico y Amat defined them as the assignment given by ministers to the members of parliament at the end of the 200 year with the aim of collecting the maximum number of votes in small towns outside the requirements fixed by the law. ${ }^{19}$ And in his description of the 1846 parliament, which had a moderate majority, Joaquin Sanchez de Fuentes highlighted the excessive use of authorisations and how, despite the knowledge that this practice was inconvenient, there was no moral strength to fight this problem. In his opinion, it 205 was very easy to govern with the system of authorisations and, above all, to grant them with no distinction of political nuances, all of which came about as the result of parliamentary majorities. ${ }^{20}$

\section{THE SPANISH PENAL CODE OF 1848 AS A PARADIGMATIC EXAMPLE OF} LEGISLATIVE DELEGATION

One of the most significant legal texts approved by Narváez's third moderate government (1847-1851) is, without the shadow of a doubt, the 1848 Penal Code. ${ }^{21}$ This penal text, drawn up by the general codification commission, created in

${ }^{18}$ Marcuello Benedicto, La practica parlamentaria, p. 95.

${ }^{19}$ Rico y Amat, Diccionario de los políticos, pp. 118-9.

${ }^{20}$ J. Sánchez de Fuentes, Fisonomía de las Cortes de 1846 (Madrid, 1850), p. 138.

${ }^{21} \mathrm{~A}$ modern edition of the Code in J. López Barja de Quiroga, J. Rodríguez Ramos, and L. Ruiz de Gordezuela López, Códigos penales españoles, 1822, 1848, 1850, 1928, 1932, 1944 (Madrid, 1988), J. F. Pacheco, El Código penal concordado y comentado, 3 vols (Madrid, 1848, 1st ed.), J. Antón Oneca, 'El Código penal de 1848 y Don Joaquín Francisco Pacheco', Anuario de Derecho Penal y Ciencias Penales 18, (1965), pp. 473-95. J.F. Lasso Gaite, Codificación Penal. Crónica de la Codificación Española, vols. I and II (Madrid, 1970), M.D. Sánchez González, La Codificación penal española: los Códigos de 1848 y 1850 (Madrid, 2004), E. Iñesta Pastor, El Código Penal Español de 1848, Doctoral Thesis (Alicante, 2005), (forthcoming). 
1843 , brought a long period characterised by the absence of a systematised penal legislation to an end, since it replaced the outdated Ancien Régime penal legislation. Its structure and scientific orientation were to exert a recognised influence, not only on the future Spanish Penal Codes until the one in force from 1995, but also on Latin America. ${ }^{22}$.

The penal text ensured the defence of the legal values created by the organisation of the moderate state, although it is necessary to point out that the Penal Code represented a technical type of reform, the need for which was felt by every representative of liberalism. No political bias played a significant role in the creation of the general codification commission. ${ }^{23}$

The moderate government used legislative delegation to present the project of Penal Code and have it approved by the parliament assembly. Its analysis is of particular interest, because it constitutes an exceptional illustration of how the chambers not only did not constrain the government's legislative initiative but, instead, extended it by granting the government extraordinary powers for its future reform.

The possibility of resorting to legislative delegation was defended by the general codification commission ${ }^{24}$ and by contemporary doctrine. Thus, Francisco de Cárdenas, in the journal El Derecho Moderno [The Modern Law], considered that it was in tune with the spirit of the Constitution which demanded the passing of the laws, but not the need to discuss them ${ }^{25}$. However, there were also critics, among whom the progressive Ruiz Canejares stood out. For him, Congress did nothing but grant authorisations. ${ }^{26}$

During the 1847-48 legislative session, Juan Bravo Murillo, the Justice Minister in the Cabinet presided over by Carlos Martínez de Irujo, Duke of Sotomayor,

\footnotetext{
${ }^{22}$ For the influence exerted by the Spanish Penal Codes on Latin American codification, see E. Iñesta Pastor, 'La proyección hispanoamericana del Código Penal español de 1848', Estudios, Actas del XIII Congreso del Instituto Internacional de Historia de Derecho Indiano (San Juan de Puerto Rico, 2003), II, pp. 493521, E. Iñesta Pastor 'El Código Penal chileno de 1874', Revista Chilena de Historia del Derecho 19, (2006), pp. 293-328, E. Iñesta Pastor, 'La reforma penal del Perú independiente: El Código Penal de 1863', Actas XV Congreso Del Instituto Internacional de Historia del Derecho Indiano, vol. II (Córdoba, Spain, 2008), pp. 1071-98.

${ }^{23}$ It was expressed in these terms by Manuel Seijas Lozano, editor of the Code in the Congress, RPPC, 1847-48, 10 March 1848, p. 1714. Similarly, it is necessary to take into account the determination of successive governments to keep the project of Penal Code going. Comellas, Los Moderados en el poder, pp. $213-52$.

${ }^{24}$ It must be remembered that during the process of elaboration of the Penal Code draft, the first Narváez Government addressed the General Codification Commission in September 1844, to ask whether it would be advisable to obtain an authorisation to publish the codes and to implement them. The Commission objected to their discussion at the parliament, because the unity of the texts would be compromised. Archive of the Ministry of Justice General Codification Commission (hereinafter $\mathrm{ACGCM}^{\circ} \mathrm{J}$ ), dossier 1 on the Organisation of the Commission, 3rd folder: 'Organisation and Works of the Commission', single document: 'Abstracts from the Secretary's Office', fol. 27).

${ }^{25}$ F. de Cárdenas, 'De la autoridad competente para hacer la reforma penal', El Derecho Moderno, Revista de Jurisprudencia y Administración I, (1848), pp. 116-9.

${ }^{26}$ Record of Parliamentary Proceedings, Congress (hereinafter RPPC), 1847-48, No.82, 14 March 1848 , p. 1779.
} 
promoted a legislative authorisation bill for the publication of the Penal Code before the Senate on 13 February $1847 .^{27}$

The authorisation bill was accompanied by a statement of motives which justified the choice of method selected for the passing of the code based on the urgency of penal reform, the technical complexity and length of the work and, above all, on the repeated use at the time of the legislative delegations granted to the government to publish, and even to create shorter-length laws as important as the Penal Code or even more important ${ }^{28}$.

The text submitted for the approval by the parliament assembly was a bill of law signed by Juan Bravo Murillo which consisted of three articles: ${ }^{29}$

1) 'The project for a Penal Code presented by Her Majesty's government and the provisional law which accompanies it, by which rules are established for the application of the provisions contained in the same code, for the time being and until the publication of the text referring to procedures and the law about the constitution of courts, will be published and observed in the Iberian Peninsula and its adjacent islands, and will be in force from 1 July of the present year.'

2) 'From this very date, all laws, royal decrees, orders and provisions to the contrary are repealed.'

3) 'The government will adopt the measures required for the enforcement of this law.'

In accordance with the procedure foreseen for the legislative processing in the Senate, the commission responsible for providing information about the legislative bill for the publication of the Penal Code and for preparing the corresponding report $^{30}$ was appointed on 20 February 1847. This task was not completed, however, because the government collapsed on 28 March 1847.

During the new legislative session, which started on 15 November 1847, in the third Narváez government with Lorenzo Arrazola as justice minister, a second commission was established in the Senate ${ }^{31}$ to prepare the report which authorised the government to publish the Penal Code. This modified Juan Bravo Murillo's authorisation bill, making it even more favourable to the government's interests. $^{32}$

\footnotetext{
${ }^{27}$ Record of Parliamentary Proceedings. Senate (hereinafter RPPS), 1846-47 legislative period, No.17, 13 February 1847, pp. 177-8. The Bill is in the Appendix, pp. 179-216.

${ }^{28}$ RPPS, 1846-47, 13 February 1847, Appendix to No. 17, p.179.

${ }^{29}$ RPPS, 1846-47, 13 February 1847, Appendix to No. 17. p.180.

${ }^{30}$ The Commission comprised Ángel Casimiro Govantes, Juan Nepomuceno Fernández San Miguel, 310 Juan Narciso Gallego, Juan Antonio Castejón and Claudio Antón de Luzuriaga. RPPS, 1847-48, 20 February 1847, No. 18, p. 219. The text of the Penal Code presented by the Commission in the archive of the General Codification Commission is in dossier 3 of the Penal Code: Código Penal de 1848 (trabajos para su redacción), $3^{\text {rd }}$ folder: Tres manuscritos completos, $A$, B y C, del Anteproyecto, Doc. 3: Manuscrito C, Anteproyecto elevado al Ministro el 23 de diciembre de 1845.

${ }^{31}$ This second Commission comprised Francisco Olavarrieta, Gualberto González, Barrio Ayuso, Castejón and Claudio Antón de Luzuriaga.

${ }^{32}$ RPPS, 1847-48, No. 21, 3 January 1848, p. 311.
} 
The report was read in the upper chamber on 31 January 1848, emphasising how urgent it was to carry out a penal reform and the inability of the chambers to debate a Penal Code without threatening its structure. Nevertheless:

in order to overcome any possible scruples, (the commission) has thought that the most advisable option is to recommend the government to watchfully monitor the effects which are gradually produced by the application of the code, leaving it in its hands to propose to the parliament assembly the introduction of the reforms demanded or advised by experience and to confer upon the government the powers to carry out those which turn out to be urgent, with the only condition that the parliament assembly be informed. ${ }^{33}$

The comparison between the original text of the authorisation bill of law presented by Juan Bravo Murillo on 13 February 1847 and the later version of the authorisation act contained in the report presented by the commission on 31 January 1848, reveals important variations. ${ }^{34}$

1) Two important modifications are easily identified in the first article: both paragraphs that established 1 July as the date on which the code was to come into force, as well as the references to the procedures act and the courts act to justify the provisional law, were deleted. The new wording was as follows: 'The project of Penal Code presented by the government and the provisional law which accompanies it for its application are published and will be observed as a law in the peninsula and its adjacent islands, from the day fixed by the government within four months from the date of the royal assent'.

2) The clause abolishing the previous text was removed from the second article, the new wording being: 'the government will propose to the parliament in three years, or earlier, should this be considered appropriate by the government, reforms or improvements that need to be introduced in the code, attaching the commentaries that at least once a year will be made on it by the courts'.

3) A new third article was introduced: 'The government will make on its own any reform proposed by the courts, if this is urgent reporting to the parliament as soon as possible'.

4) The fourth article modified the old 3rd article: 'The government will adopt the appropriate provisions required for the execution of this law'.

The authorisation act was accompanied by the text of the Penal Code so that the latter could be passed as a law - and by the provisional law for its application.

The study of the record of the Senate and Congress Proceedings, dedicated to the discussion of the authorisation act presented for the approval of the 1848 Penal Code provides an excellent source for the analysis of the different positions held by moderates and progressives towards the issue of legislative delegation, as well as their different political approaches in the treatment of penal issues.

\footnotetext{
${ }^{33}$ RPPS, 1847-48. January 31st, 1848, No. 27, 3rd Appendix No. 27, pp. 397-8.

${ }^{34}$ RPPS, 1847-48. January 31st, 1848, No. 27, 3rd Appendix No. 27. p. 398.
} 
A general characteristic of the debates in both chambers ${ }^{35}$ was the lack of interest shown by their members. This is demonstrated by the speed of the discussion (they only dedicated to it three sessions at the Senate and six in the Congress) and the high absenteeism of the members of both chambers, even though they were dealing with something as important as penal issues. ${ }^{36}$ The social relevance of the matter which practically escaped parliamentary discussion was highlighted by the progressives, who emphasised its close link with the rights of the individual and fundamental laws. ${ }^{37}$

This lack of interest clearly had a twofold explanation: the proximity to the government of most members of the chamber, ${ }^{38}$ and the mechanism by which the passing of the Penal Code was put forward through an authorisation act, as it became evident that the main purpose was to obtain a vote of confidence, something criticised among opposition ranks. ${ }^{39}$ Finally, it must be remembered that the debates took place within the context of political upheaval that followed the European revolutionary events of $1848 .{ }^{40}$ As a strong text in which political crimes were severely punished and where the sentences established had to be

\footnotetext{
${ }^{35}$ For a list of the members of the Senate and the Congress see N. Pastor Díaz and F. de, Cárdenas, Galería de Españoles célebres contemporaneous (Madrid, 1841-1846), B. Moratilla, Estadística del personal y vicisitudes de las Cortes de los Ministerios (Madrid, 1858). J. Rico y Amat, El libro de los diputados, L. Chinchón, Biografías de Jurisconsultos españoles publicadas por la Academia de Jurisprudencia y Legislación (Madrid, 1911), J.F. Lasso Gaite, El Ministerio de Justicia. Su imagen histórica (1714-1981) (Madrid, 1984), F. Ruiz Cortés and F. Sánchez Cobos, Diccionario biográfico de personajes históricos españoles del siglo XIX español (Madrid, 1998).

${ }^{36}$ Barrio Ayuso and Cándido Nocedal expressed these views at the Senate and Gómez de la Serna at the Congress, RPPS, 1847-48, No.30, 14 February 1848, p. 474. RPPC, 1846-47, No.81, 1 March 1847, p. 1757, No.82, 14 March 1847, p. 1765.

${ }^{37}$ Fernández Baeza and Gómez de la Serna, RPPC, 1847-48, 11 March 1848, No.80, p. 1732 and No.82, 14 March 1848, pp. 1765-6.

${ }^{38}$ The Senate was configured in the Constitution of 1845 as an assembly that supported the Queen, with an unlimited number of members who held their posts for life. See Enrile Aleix, El Senado en la Década Moderada, R. Bertelsen Repetto, El Senado en España (Madrid, 1974), D. Sevilla Andrés, 'El Senado de 1845', in Homenaje a Don Nicolás Pérez Serrano (Madrid, 1959), vol. II, p. 18. The Congress which submitted the Penal Code to a vote was elected by censitary suffrage in accordance with the Moderate Election Act of March 1846. Its composition derived from the election held by the Istúriz Cabinet on 6 December 1847. Although the results gave a large majority to the Moderates, 252 representatives, the Progressive opposition experienced a dramatic growth, some of its most outstanding members being 395 Manuel Cortina, Francisco Olózaga, Juan Álvarez Mendizábal, Evaristo Fernández San Miguel, Sancho, Francisco Luján and Pedro Gómez de la Serna. See: M. Martínez Cuadrado, Elecciones y Partidos políticos de España (Madrid, 1969), vol. I, p. 63, Artola, Partidos y Programas políticos, I, pp. 49-50, M. Fernández Almagro, 'Las Cortes del siglo XIX y la práctica electoral', Revista de Estudios Políticos 5, (1943), pp. 383416, E.J. Ull Pont, 'El sufragio censitario en el Derecho electoral español', Revista de Estudios Políticos 165-196, (1974), pp. 165-9, M.F. Monsell Cisneros, and R.L. Pérez Díaz, 'La práctica electoral en el $400 \quad$ reinado de Isabel II', Revista de las Cortes Generales 16, (1989), pp. 143-77, A. Fernández Domínguez, Leyes Electorales Españolas de Diputados a Cortes en el siglo XIX (Madrid, 1992), p. 91.

${ }^{39}$ Gómez de La Serna and Ruiz Canejares, RPPC, 1846-47, No.83, 15 March 1847, p. 1779.

${ }^{40}$ Despite the backdrop of the European revolutionary events, the Spanish events in 1848 were not directly related to them. The riots were caused by groups with very different affiliations. See V. Palacio Atard, La España del Siglo XIX, 1808-1898 (Madrid, 1981), pp. 267-73, S. Cabezas 405 Sánchez Albornoz, Los movimientos revolucionarios de 1820, 1830 y 1848 en sus documentos (Barcelona 1998), A. Eiras, El partido demócrata español (Madrid, 1961), pp. 133-4, 137.
} 
inexorably imposed, the Penal Code constituted an ideal instrument to maintain law and order. ${ }^{41}$

The meaning and scope that the legislative delegation had for the moderates became quite clear in the intervention before the Senate of the Grace and Justice Minister, Lorenzo Arrazola, who focused the object of the debate highlighting the difference between the authorisation and the reasons it. He argued that the legislative bill which accompanied the authorisation was nothing but a complement; therefore, asking for the approval of a bill by authorisation and admitting modifications would be a contradiction. However, after hearing the reasons, the government, with the consent of the parliament assembly, could introduce the appropriate modifications needed to calm the conscience of the chambers. In conclusion, the basic questions about the authorisation requested had mainly to do with the totality and then it did not matter if a discussion of the details took place. It would indeed be discussed in its entirety if the code was needed, if what was presented before the parliament was the most suitable and, finally, if the way to present it was the most appropriate. ${ }^{42}$

Similarly, during the discussion of the Penal Code, the moderates insisted on three of the arguments most often used to support legislative delegation: the chamber's inability to properly understand something as complex as penal legislation, the pressing need for its reform and, above all, its constitutionality. ${ }^{43}$ The progressive opposition strongly opposed to this.

In the opinion of some contemporaries, this criticism was not too relevant. ${ }^{44}$ However, it can be inferred from the study of the record of parliamentary proceedings that the procedure used to put the code forward did not prevent the examination of many of its precepts. There were replies and counter replies and, consequently, the objections made to the proposals cannot be regarded as being so irrelevant. Apart from the strictly penal issues, ${ }^{45}$ the analysis of these interventions reveals that the criticism focused on the way in which the text was presented and on its possible unconstitutional nature. In any case, the strongest attacks were undoubtedly directed at the second and third articles, which authorised the government to reform the code. Once the authorisation bill had received a favourable report, the discussion at the Senate started on 14 February 1848 , and finished on the 16th of the same month. The suitability of the system

\footnotetext{
${ }^{41}$ The influence of 'moderantism' (the Moderate approach) gave the code a certain tone of harshness which is particularly visible in the references to crimes against the State and against religion. L. Jiménez de Asua, Tratado de Derecho Penal (Buenos Aires, 1964), vol. I, p. 758, Antón Oneca, 'El Código penal de 1848', p. 485, L.R. Núñez Barbero, La Reforma penal de 1870 (Salamanca, 1969), p. 13, M. Barbero Santos, Politica y Derecho Penal en España (Madrid, 1977), pp. 28-9.

${ }^{42}$ RPPS, 1847-48, No.31, 15 February 1848, p. 493.

${ }^{43}$ RPPS, 1847-48, 14 February 1848, No.30, p. 474. The Grace and Justice Minister, Lorenzo Arrazola, underlined how debates led to confusion (RPPC, 1847-48, No.83, 15 March 1848, p. 1800).

${ }^{44}$ Joaquín Francisco Pacheco, El Código Penal, I, p. LVIII, T. M. de Vizmanos and C. Álvarez Martínez, Comentarios al nuevo Código penal (Madrid, 1848), vol. I., p. XLIII.

${ }^{45}$ The most common objections referred to aspects such as political and religious crimes, crimes against property, those committed by public servants, injuries, the system of punishments and sentences and its measurement, the death penalty, excluded crimes, and a series of issues strictly associated with the penal technique.
} 
proposed for the discussion of the bill was defended by the reporting commission with a reference to the fact that the lengthy discussion article by article was incompatible with the pressing need for a new Penal Code. ${ }^{46}$ This opinion was shared by the members of the upper chamber who were politically close to the moderate party. ${ }^{47}$

Nevertheless, the way to present the code before the chambers was strongly criticised by the progressive senator, Francisco Cabello, who insisted on the fact that the debate in the chambers was essential, and argued that the time to propose reforms should be annual, instead of doing it every three years as was stipulated in the second article, and that there should always be the inescapable requirement to bring them for examination by the parliament. He made it equally clear that the third article represented an abdication of the parliament's right to elaborate the laws in favour of the government. ${ }^{48}$

Instead, a member of the reporting commission, Claudio Antón de Luzuriaga clarified that the third article only authorised partial reforms and explained that the obligation to inform parliament prevented the latter's abdication in favour of the government. ${ }^{49}$

It is especially worth highlighting the amendment to the third article presented by Manuel Pando, Marquis of Miraflores, who suggested that the demand for the reforms to be proposed by courts should be removed, because, in his opinion, the code was a public interest issue. The amendment was accepted, after which the third article read: 'The government will make any reform, if this is urgent, letting the parliament know about it as soon as possible'. 50

We must emphasise the relevance of the Miraflores' amendment, because it served to substantially enlarge the powers requested by the government, and exceeding, in fact, the scope of what had been initially requested. This justified its favourable reception by the government. ${ }^{51}$ After all, thanks to this amendment, the executive power was authorised to reform the Penal Code, in urgent cases, on its exclusive initiative and discretion, the only condition being the requirement to 480 inform the parliament. This guarantee was extremely vague, as no time period was fixed for it, and nor was it specified whether this consisted of a mere verbal communication to the assembly with no further effects or whether this subjected the reforms decreed to the later examination and approval by parliament. ${ }^{52}$

On 16 February 1848, the justice minister concluded the debates at the Senate by proclaiming the benefits that an enactment of the code would entail. He did not rule out the possibility for an improvement of the code at a later stage, but made it

${ }^{46}$ RPPS, 1847-48, No.30, 14 February 1848, p. 474.

${ }^{47}$ This was done by Armendáriz, Bishop of Córdoba, and Manuel Pando, Marquis of Miraflores, amongst others, RPPS, 1847-48, Nos.30, 31 and 32; 14, 15 and 16 February 1848, p. 471, p. 488 and pp. 504-5.

${ }^{48}$ RPPS, 1847-48, No.32, 16 February 1848, p. 503.

${ }^{49}$ RPPS, $1847-48$, No.32, p. 510.

${ }^{50}$ RPPS, 1847-48, No.32, p. 505.

${ }^{52}$ Marcuello Benedicto, La Practica Parlamentaria, p. 251. 
clear that the reforms were an exclusive competence of the executive. The Penal Code was finally passed by the Senate. ${ }^{53}$

After having been approved at the Senate, the bill of law which authorised the government to present the Penal Code was sent to the Congress on 16 February $1848 .^{54}$ In compliance with what was foreseen, the lower chamber proceeded with the appointment of the reporting commission on 22 February $1848,{ }^{55}$ and on 3 March, the report was brought before the chamber and the text presented by the Senate was endorsed. ${ }^{56}$ The debates in the lower chamber started on 10 March 1848 and carried on until the 16th of the same month.

At the Congress, Francisco Muñoz Maldonado, Count of Fabraquer, criticised the way in which the Penal Code was presented before the chambers because, the latter would only have two alternatives: either to be content with it or to deny it their vote. ${ }^{57} \mathrm{He}$ was also against its reform without the parliament's intervention since that meant giving the government an absolute confidence vote to change anything that it should think appropriate, thus leaving the parliament at the mercy of the government. ${ }^{58}$ The answer came from Manuel Seijas Lozano, who highlighted how the legislative delegation was used by all the countries ruled by a constitutional system, and also by the progressive party. ${ }^{59}$ He defended the impartial character of the reporting commission and finally referred to a series of technical reasons. ${ }^{60}$

On the other hand, it is necessary to highlight the enthusiasm shown by those close to the moderate party in the defence of the legislative delegation, as some of them even requested the enlargement of its scope. Along these lines we may include the intervention by Federico Roncali, whose main argument was that this was a question of trust. ${ }^{61}$ Antonio María Coira proposed the extension of the legislative delegation to the procedures act for reasons of personal urgency. ${ }^{62}$ Such proposals, however, were considered excessive. ${ }^{63}$

${ }^{53}$ RPPS, 1847-48, No.32, 16 February 1848, p. 515.

${ }^{54}$ RPPC, $1847-48$ up to No.65, p. 1263.

${ }^{55}$ It comprised Pedro José Pidal, Ventura González Romero, Manuel Seijas Lozano, Gregorio de Miota, Fernando Calderón Collantes, Cándido Nocedal and Claudio Moyano. RPPC, No.65, 184748, pp. 1358 and 1376.

${ }^{56}$ RPPC, 1847-48. No.76, 3rd Appendix, pp. 1591-1629.

${ }^{57}$ RPPC, 1847-48. No.76, 3rd Appendix. p. 1712.

${ }^{58}$ RPPC, 1847-48. No.76, 3rd Appendix. p. 1712.

${ }^{59}$ Manuel Seijas referred to the Authorisation requested by the Count of Ofalia at the 1838 Parliament for the purpose of rewriting the Civil Procedure Code and the Criminal Code in a single text. In that case, the legislative delegation only referred to the issue, since the content of the Bill was not made known, and the Progressives responded with their majority vote. The Count of Fabraquer himself belonged to that parliament as did outstanding Progressive figures like Olózaga and Landero. RPPC, 1847-48, No.79, 10 March 1848, pp. 1713-4.

${ }^{60}$ Manuel Seijas said 'in special matters, it is necessary for the laws to be elaborated by special men; and when it comes to Codes, a principle of unity must prevail... in all its provisions... the discussion in the chambers does nothing but vitiate it'. RPPC, 1847-48, No.79, 10 March 1848, p. 1714.

${ }^{61}$ RPPC, 1847-48, No.80, 11 March 1848, p. 1733.

${ }^{62}$ RPPC, 1847-48, No.84, 16 March 1848, pp. 1819-22.

${ }^{63}$ Fernando Calderón Collantes argued that the parliament could not go beyond what the government was asking, RPPC, 1847-48, No.84, 16 March 1848. pp. 1819-23. 
The different positions held by moderates and progressives in the Congress also became evident in relation to the constitutional nature of the legislative delegation. Fernando Fernández Baeza and Pedro Gómez de la Serna defended its unconstitutionality based on the fact that the discussion of the laws corresponded to the parliament's role. ${ }^{64}$ Finally, the fact that legislative powers could not be waived was highlighted by José Alonso Ruiz Canejares, who reminded the other members of parliament that legislative tasks were a duty of the chambers and not a right which could be renounced by delegating it to the government. ${ }^{65}$

The government defended the opposite stance through a speech by Fernando Calderón Collantes, pointing out that everything which, according to the constitution, necessarily had to be achieved through a law could be also be achieved by means of an authorisation - freely and spontaneously granted by the parliament - and sanctioned by the crown. ${ }^{66}$ Fernando Arrazola's opinion was similar. He underlined the fact that the constitution had not determined the way to debate in the chambers, leaving it to the respective regulations, which could be modified without incurring any responsibilities. ${ }^{67}$

It is worth bearing in mind the amendments presented during the discussion of the authorisation act. All of them represented an attempt to limit the scope of the reforming powers granted to the government and, at the same time, to set out 560 specific aspects of the code for debate, such as the regulation of political crimes, religious crimes or secret societies - aspects that ultimately also revealed the disparity of criteria between progressives and moderates.

Seeking to reduce the severity of the punishments for political crimes, an amendment was presented to the first article of the authorisation act in which a 565 request was made for the punishments of death penalty and life imprisonment mentioned in the first and second paragraphs of Article 168 in the Penal Code to be replaced by perpetual or temporary banishment. ${ }^{68}$ This was defended by Pedro Gómez de la Serna, who made it clear that the time had come to say no more blood for political crimes. ${ }^{69}$ However, this was rejected by Manuel Seijas Lozano, who reminded those present of the key issue for discussion: the commission could not examine the Penal Code article by article, only the authorisation to propose it. ${ }^{70}$ After being voted on, this amendment was disregarded. ${ }^{71}$

The progressives presented an amendment to the third article as well:

\footnotetext{
${ }^{64}$ RPPC, 1847-48, No.80, 11 March 1848, p. 1733 and No.82, 14 March 1848, pp. 1765-66.

${ }^{65}$ RPPC, 14 March 1848, No.82, p. 1779.

${ }^{66}$ RPPC, 1847-48, No.80, 11 March 1848, p. 1738.

${ }^{67}$ RPPC, 1847-48, No.83, 15 March 1848, p. 1801.

${ }^{68}$ It was signed by the Progressives Gómez de la Serna, Gálvez Canero, G. Gasco, Tomás Pérez, Jaén and the Marquis of Albaida. RPPC, 1847-48, No.80, 11 March 1848, p. 1726.

${ }^{69}$ RPPC, 1847-48, No.81, 13 March 1848, pp. 1742-45.

${ }^{70}$ RPPC, 1847-48, No.81, 13 March 1848, pp. 1745-47.

${ }^{71}$ Not only did members of the Progressive Party like Olózaga, Fernández Baeza, José Alonso, Pascual Madoz, Narciso de la Escosura, José Orozco, José Maria Orense, the Marquis of Albaida, and Manuel Cortina, etc, vote in favour, some Moderates like Luis Mayans and Andrés Borrego also did so. All this demonstrates that opinions within the ruling party about the treatment of political crimes were not unanimous. RPPC, 1847-48, No. 81, 13 March 1848, p. 1726.
} 
Instead of the second rule of the provisional law for the application of the provisions contained in the Penal Code, what follows will be observed: When the criminality of the accused results with certainty from the cause, the courts will impose the sentence foreseen in the code, even in the absence of one or some of the circumstances which provide full evidence according to the current legislation. ${ }^{72}$

In its defence, Luis Mayans highlighted the contradiction between the third article and the first article, already approved, expressing that the fortune, life and honour of the Spaniards was handed over to the government, the code thus being at the mercy of any ministerial change that could alter it in discretionary way. ${ }^{73}$ He spoke against Claudio Moyano, who in turn highlighted the contradiction represented by Luis Mayans himself, reminding him that while he had formed part of the government, authorisations were requested explaining only the matter that had to be legislated in such important issues as town councils, provincial administration and tariffs or duties. ${ }^{74}$ This amendment was finally rejected. $^{75}$

Another amendment to the third article was read during the session of 16 February. This one suggested restricting the application of capital punishment strictly to the crimes specified in the code. ${ }^{76}$ Defended by Mr Julián Huelves, it sought to prevent the government from extending the death penalty to crimes that had not 605 been initially planned. ${ }^{77}$ As in the case of the previous amendments, this was not taken into account.

The final speaker was Andrés Borrego, who maintained a position similar to that of Luis Mayans. His intervention referred to the treatment of issues with a special political relevance, such as secret societies and the death penalty in political crimes 610 involving rebellion. ${ }^{78}$ The answer came for the grace and justice minister, who reminded him that the aim of a Penal Code is the sanction of established laws, and consequently, it would only be the government's competence to enforce what is established in those laws. Regarding the imposition of the death penalty for rebellion, he underlined that extending capital punishment beyond the cases specified in the code exceeded the government's capacity to reform, as this capacity was confined to removing possible inconsistencies and contradictions, and always with the constraint that the courts could later inform the parliament. The government could only present them directly in urgent cases and, furthermore, before the code had been published. ${ }^{79}$

\footnotetext{
${ }^{72}$ It was signed by Mayans, Pardo Montenegro, the Marquis of El Puerto, Piera, García Tassara, Lafuente and Gómez La Serna. RPPC, 1847-48, No.81, 13 March 1848, p. 1751.

${ }^{73}$ RPPC, 1847-8, No.84, 16 March 1848, pp. 1809-11, 1816.

${ }^{74}$ Luis Mayans was the Justice Minister in Luis González Bravo's Government in 1843 and with Narváez. RPPC, 1847-8, No.84, pp. 1816-1817.

${ }^{75}$ RPPC, $1847-8$, No.84, p. 1818.

${ }^{76}$ The amendment was presented by Félix Martín, José Pedro Muchada, José Orozco, the Marquis of Albaida, Luis Sagasti and Julián Huelves. RPPC, 1847-48. No.76, 3rd Appendix and No.79, 10 March 1848 , p. 1705.

${ }^{77}$ RPPC, 1847-48, No.84, 16 March 1848, pp. 1818-19.

${ }^{78}$ RPPC, 1847-48, No.84, 16 March 1848, p. 1824.

${ }^{79}$ RPPC, 1847-48, No.84, 16 March 1848, pp. 1827-8.
} 
According to the documentation provided to us by the record of parliamentary proceedings, the bill of law which authorised the government to present the Penal Code was finally passed on 17 March $1848 .{ }^{80}$ Queen Isabel II gave it her assent on the 19th of the same month and the enactment of the Penal Code took place through a royal decree dated on the same day. It was set to come into force from 1 July of the same year. ${ }^{81}$

By virtue of the empowerment granted by the law of 19 March 1848, and considering practical needs, ${ }^{82}$ Narváez's Moderate cabinet proceeded to reform the Penal Code by way of urgency through a cascade of royal decrees. And in compliance with the demand contained in the third article of the authorisation act, which forced it to let parliament know about the reforms as soon as possible, the government sent simple communications to the chambers, without allowing any sort of debate. This demonstrated once again how Narváez's moderate government understood the use of legislative delegation. ${ }^{83}$

645 Shortly after the enactment of the code, it was reformed by the successive decrees of 21 and 22 September 1848. Similarly, the application of some of its provisions was suspended by a Decree of 30 November of the same year. ${ }^{84}$ The most ambitious reform of the code was carried out through a royal decree of 7 June $1850 .^{85}$

650 As for the way in which the reforms were implemented, it must be said that they were carried out by the grace and justice minister, Lorenzo Arrazola. In principle, they had to be made with the consent of the general codification commission, bearing in mind the remarks, consultations and reports provided by courts, institutions, political, religious and military authorities, but not all the reforms counted on such a wide participation. ${ }^{86}$

\footnotetext{
${ }^{80}$ It was signed by Alejandro Mon, Gabriel Tessara, Miguel Lafuente Alcántara, Julián Huelves and Manuel Sánchez Silva. RPPC, 1847-48, No.85, 17 March 1848, p. 1849. For the text of the Penal Code, see pp. 1849-87.

${ }^{81}$ RPPC, 1847-48, No.87, 20 March 1848, p. 1929. Handwritten copy in ACGCM ${ }^{\circ}$ J, dossier 19, 3rd folder, Doc. 2.

${ }^{82}$ J. González Miranda and J. Pizarro, Historia de la Codificación Penal Española y ligera crítica del Código Penal vigente (Madrid, 1907), p. 20.

${ }^{83}$ The Grace and Justice Minister, Lorenzo Arrazola, sent the Congress several communications 665 accompanied by Royal Decrees: Two communications during the 1848/49 legislative period, dated 21 December 1848 and 8 June 1849, in which were justified the provisions contained in the Royal Decrees given on 21,22 and 30 October 1848, and on 30 May and 2 June 1849 to reform the Penal Code and the Provisional Law. (RPPC, 1848-49, No.7, 27 December 1849 and No.109, 1 February 1849. There was another communication during the 1850-51 legislative period dated 9 November 1850, which informed the Congress about the reforms introduced by the Royal Decrees of 7,8, 9, and 67030 June 1850. RPPC, 1848-49, No.10, 24 November 1850. The original manuscript in the Congress, ACD. Serie General, dossier 66, Doc.79. ACGCMJ, dossier 19, 14th folder, Doc.1.

${ }^{84}$ Leaflet published in Madrid in 1848 with the provisions referring to the Penal Code, $\mathrm{ACGCM}^{\circ} \mathrm{J}$, dossier 19 of the Penal Code, 8th Folder, Doc. 5.

${ }^{85}$ Colección Legislativa de España, Madrid, 1850, No.503, p. 356. The original in ACGCM ${ }^{\circ}$ J, dossier 19 of the Penal Code, 18th folder: Doc. 1.

$675 \quad{ }^{86}$ The reports ACGCM ${ }^{\circ}$ J, Penal Code Section, dossiers 5, 6, 7 and 8, Codification Commission and its organisation: dossiers 4 and 5 .
} 
The number of modifications introduced along with their scope led to a second edition of the Penal Code, which materialised in the revised text of 1850, enacted by royal decree of 30 June of the same year. ${ }^{87}$ One of the most important commentators on the code, Francisco Pacheco, defended the original wording of 1848 and complained about the solution adopted in 1850, as it modified the code's politicalcriminal orientation and was rather the result of the fear generated by the European revolutionary events of 1848. This is the widespread opinion among criminal lawyers. ${ }^{88}$ In our opinion, the primitive wording of 1848 reflected the position of the general codification commission of 1843 , formed by individuals with different ideologies. Instead, the reformed edition of 1850 can be associated with the moderate ideas, which means that a connection existed between the Constitution of 1845 and the Penal Code of 1850. Its political-criminal orientation becomes evident in the penalisation of conspiracy and the proposal to commit an offence, the greater severity in the treatment of political crimes and the inclusion of completely new criminal figures, such as disrespect for the duly constituted authority (contempt of court) and attack against it. ${ }^{89}$

The parliamentary functioning system in the Spain of the first half of the nineteenth century is characterised by the predominance of the government's legislative initiative to the detriment of the parliament. This was favoured by the constitutional silence about the procedure for the elaboration of laws in the moderate constitution of 1845 , the regulations of the Congress and Senate and, above all, the utilisation of legislative delegation, particularly excessive in the period known as the Moderate Decade (1844-1854) during the reign of Isabel II.

The Penal Code of 1848 is undoubtedly a clear example of legislative delegation. Its processing by the parliament made it possible to enlarge the government's powers to a great extent, and also highlighted the different position held by the moderate and progressive parties regarding the significance and scope of the legislative delegation.

\footnotetext{
${ }^{87}$ Gaceta de Madrid, between 10 and 19 July 1850. ACD. Serie General, dossier 62, Doc. No.3.

${ }^{88}$ Pacheco, El Código Penal, vol. I, pp. 105 and ff., F. de Cárdenas, 'Observaciones sobre la ultima reforma del Código Penal contenida en el Decreto de 7 de junio', El Derecho Moderno 8, (Madrid, 1850), p. 418. J. Antón Oneca, Derecho Penal (Madrid, 1986), p. 76, Núñez Barbero, Reforma penal de 1870, pp. $14-15$.

${ }^{89}$ For the political significance and scope of this modification, see G. Rodríguez Mourullo, 'La punición de los actos preparatorios’ Anuario de Derecho Penal y Ciencias Penales 21, (1968), p. 281.
} 